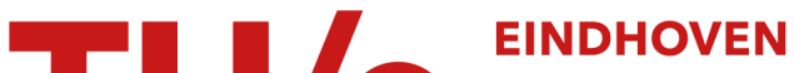 UNIVERSITY OF TECHNOLOGY
}

\section{Ultra-high-strength polyethylene filaments by solution spinning/drawing}

Citation for published version (APA):

Smith, P., \& Lemstra, P. J. (1980). Ultra-high-strength polyethylene filaments by solution spinning/drawing. Journal of Materials Science, 15(2), 505-514. https://doi.org/10.1007/BF02396802,

https://doi.org/10.1007/BF00551705

DOI:

10.1007/BF02396802

10.1007/BF00551705

Document status and date:

Published: 01/01/1980

\section{Document Version:}

Publisher's PDF, also known as Version of Record (includes final page, issue and volume numbers)

\section{Please check the document version of this publication:}

- A submitted manuscript is the version of the article upon submission and before peer-review. There can be important differences between the submitted version and the official published version of record. People interested in the research are advised to contact the author for the final version of the publication, or visit the $\mathrm{DOI}$ to the publisher's website.

- The final author version and the galley proof are versions of the publication after peer review.

- The final published version features the final layout of the paper including the volume, issue and page numbers.

Link to publication

\section{General rights}

Copyright and moral rights for the publications made accessible in the public portal are retained by the authors and/or other copyright owners and it is a condition of accessing publications that users recognise and abide by the legal requirements associated with these rights.

- Users may download and print one copy of any publication from the public portal for the purpose of private study or research.

- You may not further distribute the material or use it for any profit-making activity or commercial gain

- You may freely distribute the URL identifying the publication in the public portal.

If the publication is distributed under the terms of Article $25 \mathrm{fa}$ of the Dutch Copyright Act, indicated by the "Taverne" license above, please follow below link for the End User Agreement:

www.tue.nl/taverne

Take down policy

If you believe that this document breaches copyright please contact us at:

openaccess@tue.nl

providing details and we will investigate your claim. 


\title{
Ultra-high-strength polyethylene filaments by solution spinning/drawing
}

\author{
PAUL SMITH, PIET J. LEMSTRA \\ Central Laboratory, DSM, Geleen, The Netherlands
}

This paper deals with ultra-high-strength monofilaments of linear polyethylene that are produced by solution spinning and subsequent hot drawing at $120^{\circ} \mathrm{C}$. The influence of the draw ratio on the mechanical and thermal properties of the fibres was investigated. Some salient features of a polyethylene filament with a draw ratio of 31.7 are: tensile strength at break $=3.0 \mathrm{GPa}$, Young's modulus $=90 \mathrm{GPa}$ and DSC-melting point at a scan speed of $10^{\circ} \mathrm{C} \mathrm{min}^{-1}=145.5^{\circ} \mathrm{C}$. The modulus was found to depend linearly on the draw ratio. The tensile strength tended, by contrast, to approach an upper limit at high draw ratios. Additional morphological and $X$-ray studies revealed an extremely good orientation of the macromolecules in the fibre direction of the highly drawn polyethylene monofilaments.

\section{Introduction}

Since the chain character of polymer molecules was recognized some 50 years ago many attempts have been made to exploit the intrinsically anisotropic properties of these materials. For this purpose extension and alignment of macromolecules have been studied throughout the years. Nowadays a variety of methods are known to produce orientation in polymers, such as cold, hot and zone drawing, direct and hydrostatic extrusion and radial compression of polymer rods [1-9]. In these methods the polymer is processed below its end melting point. Chain extension and alignment have also been achieved in polymer melts and solutions by the action of flow fields (see e.g. [10-16]).

Peterlin [17] pointed out that orientation of macromolecules by processing in the solid state will be much more effective than in the liquid state. This is due to the drastically higher viscosity of the solid, because of which the relaxation phenomena counteracting the molecular orientation are negligible if compared with those in the liquid. The relatively rapid relaxation of macromolecules in the liquid state, however, can be inhibited by fixation of the oriented chains in a crystalline lattice. This was demonstrated in studies on hydrodynamically induced crystallization of polyethylene from supercooled solutions that were subjected to flow [10-14]. In this process still some relaxation of the polymer molecules might have occurred, which can be judged from the properties of the crystals produced.

More recently Zwijnenburg and Pennings reported on a technique referred to as surface growth, that is performed in a Couette-type apparatus [18]. In this mode of solution crystallization a longitudinally growing polyethylene crystal is in close contact with the rotor onto which a layer of polymer molecules is thought to be adsorbed $[18,19]$. The macromolecules that are connected with the growing crystal and the rotor surface experience a continuous strain preventing the chains to return to a coiled conformation. In this manner effective extension of the molecules occurs, that is known to enhance the nucleation and growth of polymer crystals [20]. Indeed, longitudinal growth rates were measured that were substantially higher than the "freegrowth" rates in Couette flow [19]. The properties of these surface grown filaments were superior to those of the fibres obtained by hydrodynamically induced crystallization [21], longitudinal crystallization in Poiseuille and Couette flow [22], and also if compared with the characteristics of polyethylene structures generated by any solid-state process. For example, the Young's modulus and 
the tensile strength of surface grown polyethylene filaments may amount up to $100 \mathrm{GPa}$ and $3 \mathrm{GPa}$, respectively [22]. The modulus of solid-state extruded and drawn material may be as high as $70 \mathrm{GPa}$, but the tensile strength is usually found below $1 \mathrm{GPa}[23,24]$. The major disadvantage of the surface growth process of Zwijnenburg and Pennings is that until now the production rate of the longitudinal crystals is far below commercially interesting speeds [19].

In this paper we present an alternative method to produce ultra-high-strength polyethylene filaments with a Young's modulus of $90 \mathrm{GPa}$ and a tensile strength of $3 \mathrm{GPa}$. This method is based on a simple solution-spinning and hot-drawing technique that can be performed continuously and at high speeds. A preliminary account of this work was given earlier [26].

\section{Experimental}

The high molecular weight polyethylene Hostalen GUR $\left(\bar{M}_{\mathrm{w}}=1.5 \times 10^{6}\right.$ and $\left.\bar{M}_{\mathrm{n}}=2 \times 10^{5}\right)$ was used in this study. The solvent was decalin, a mixture of cis-and transdecahydronaphtalene, from J. T. Baker Chemicals. Solutions were prepared by dissolving $2 \% \mathrm{w} / \mathrm{w}$ of the polymer in decalin at $150^{\circ} \mathrm{C}$. To prevent degradation of the polyethylene, the dissolution was carried out under nitrogen and the solutions were stabilized with $0.5 \% \mathrm{w} / \mathrm{w}$ antioxidant (di-t-butyl-p-cresol).

Polyethylene filaments were spun using the experimental set up that is shown schematically in Fig. 1. The highly viscous polymer solution was pumped at $130^{\circ} \mathrm{C}$ through capillaries with diameters ranging from 0.5 to $1.0 \mathrm{~mm}$ and a length of $3.0 \mathrm{~mm}$. The as-spun liquid filament was quenched in cold water to form a gel fibre. This continuous gel filament was subsequently drawn in a hot-air oven at $120^{\circ} \mathrm{C}$ and at a strain rate of about $1 \mathrm{sec}^{-1}$, to yield a solvent free, highly oriented, polyethylene structure.

Stress-strain curves of these monofilaments were recorded at room temperature using an Instron tensile-tester (model 1195). The initial sample length was $15 \mathrm{~cm}$. It was found that variations in the speed of testing in the range 1 to $10 \mathrm{~cm} \mathrm{~min}^{-1}$ did not affect the stress-strain behaviour. A crosshead speed of $10 \mathrm{~cm} \mathrm{~min}^{-1}$ was maintained throughout this study.

Differential scanning calorimetric (DSC) measurements were carried out on unconstrained fibre specimens with a length of about $15 \mathrm{~cm}$. The calorimeter was manufactured by Perkin Elmer (DSC-II). The melting temperatures quoted in this paper invariably refer to the peak temperatures in the thermograms.

The polyethylene filaments were examined in the optical and scanning electron microscope.

Wide-angle and small-angle X-ray fibre patterns were obtained employing a flat-film camera. Nifiltered $\mathrm{CuK} \alpha$-radiation was used.

\section{Results}

The method to produce high-strength and highmodulus polyethylene fibres described in the present paper essentially comprises two steps

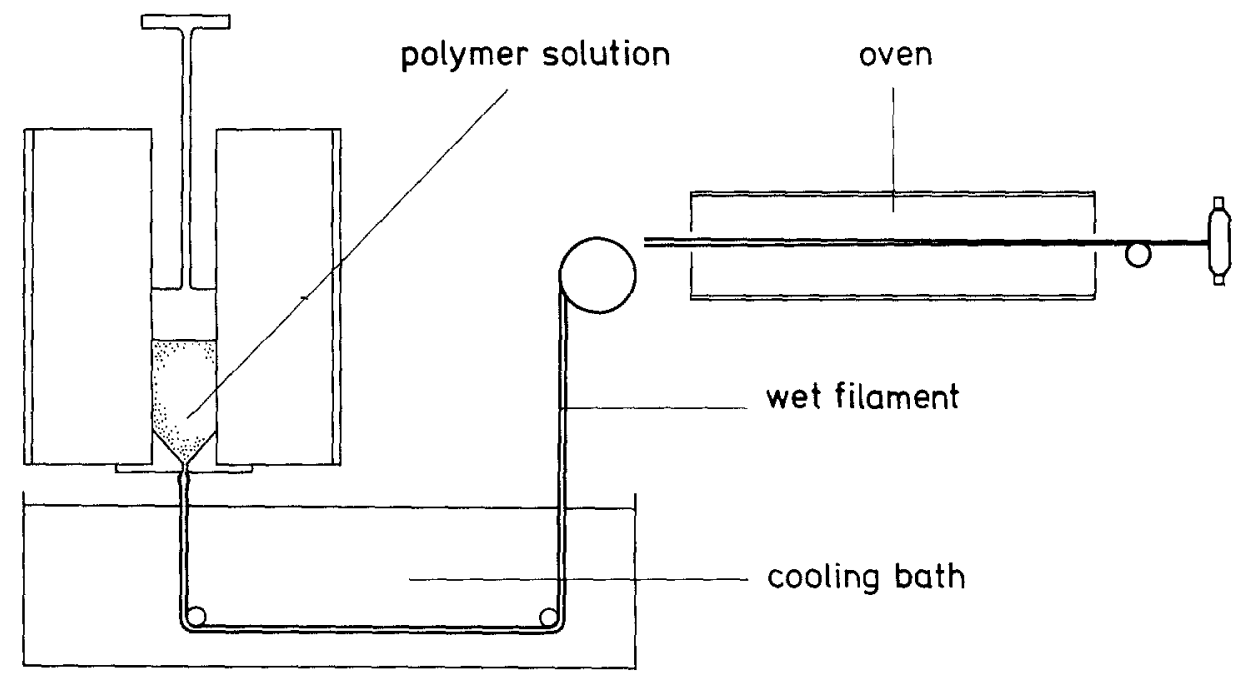

Figure 1 Schematic representation of the solution spinning/drawing process. 


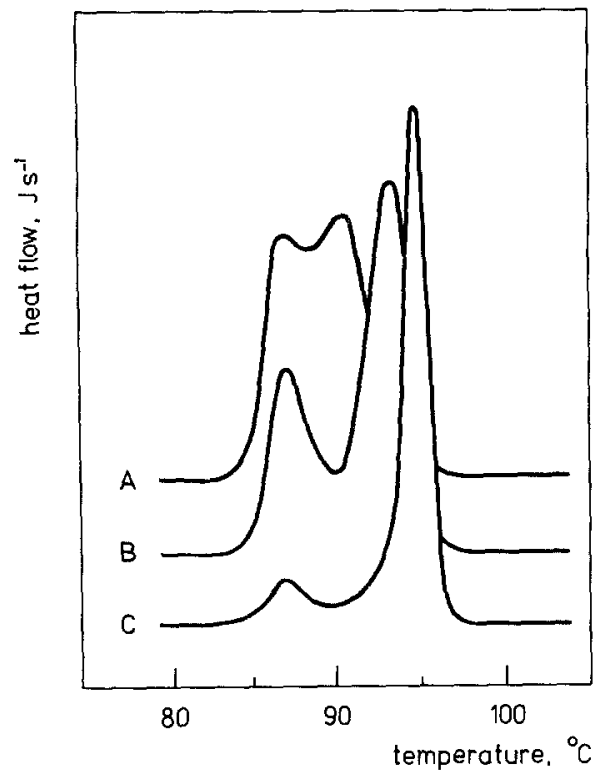

Figure 2 DSC-heating thermograms of polyethylene/ decalin gel. Scan speeds: A $40^{\circ} \mathrm{C} \mathrm{min}^{-1}$; B $20^{\circ} \mathrm{C} \mathrm{min}^{-1}$;

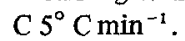

(solution spinning and hot drawing) which will be dealt with consecutively.

\subsection{Solution spinning}

In the first stage of the process the highly viscous polyethylene solution was pumped through a capillary to form a liquid filament that was subsequently quenched in a cooling bath. A gel fibre with a slightly opaque appearance was thus generated, containing almost all of the solvent.

Unexpectedly, this polyethylene gel filament appeared to be fairly strong and elastic, considering the minor amount of polymer it contained.
The load-to-break of a gel filament with a diameter of $0.7 \mathrm{~mm}$ was $49 \mathrm{~g}$, which corresponds to a tensile strength of $1 \times 10^{4} \mathrm{~Pa}$. The Young's modulus was $9 \times 10^{4} \mathrm{~Pa}$, and the elongation at break amounted to $350 \%$ at room temperature.

In order to elucidate some structural features of the gel fibres thermal analysis, optical microscopy and wide-angle X-ray scattering (WAXS) studies were performed.

Fig. 2 presents DSC-heating thermograms of the polyethylene gels that were recorded at different scan speeds. At a heating rate of $40^{\circ} \mathrm{Cmin}^{-1}$ (curve A) the thermogram was composed of two endotherms, at $87^{\circ} \mathrm{C}$ and $92^{\circ} \mathrm{C}$. Upon reduction of the scan speed the peak at the lower temperature decreased in area. The high-temperature endotherm, by contrast, increased in area and shifted towards higher temperatures at lower scan speeds. These observations are known to be a typical result of recrystallization phenomena during heating polymeric crystals [27]. Hence, it was rather problematic to measure the heat of dissolution of the polyethylene structure accurately. We nevertheless estimated its value to be $80 \mathrm{~J} \mathrm{~g}^{-1}$, which points to a low polymer crystallinity.

Fig. 3 displays a photomicrograph of the polyethylene/decalin gel fibre as it was viewed in the polarizing microscope with crossed Nicols. Evidently, an unoriented structure with little bi-refringence is seen in this figure.

A WAXS-pattern of the gel filament is shown in Fig. 4. Also from this figure it was inferred that no persistent orientation was generated during the solution spinning and quenching step. The diffraction pattern displays one broad halo and

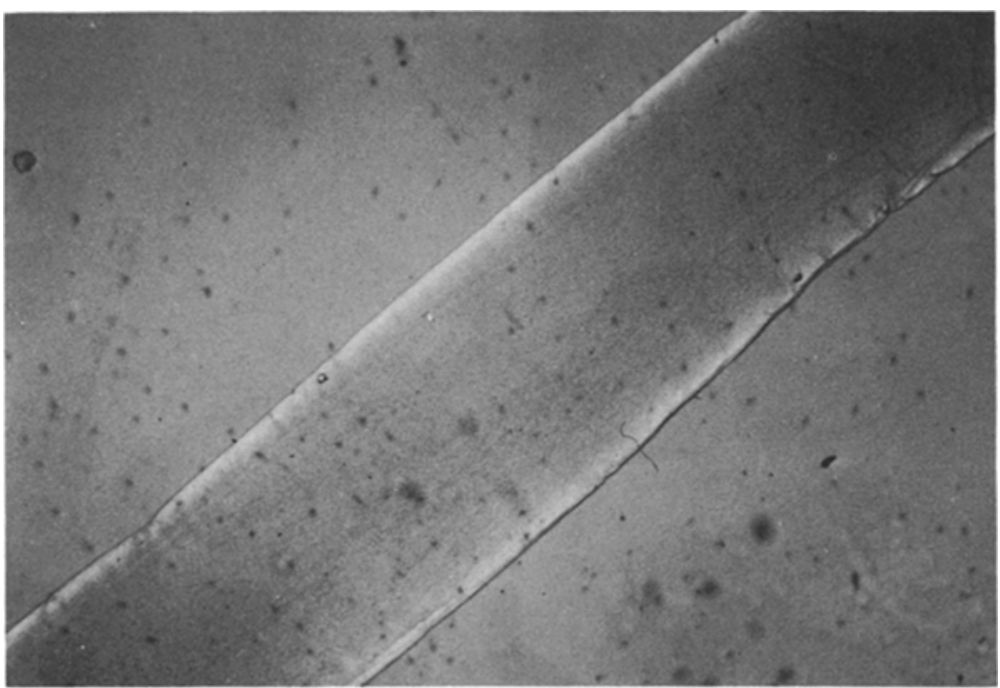

Figure 3 Optical micrograph of undrawn wet polyethylene/decalin gel. Crossed polarizers; magnification $28 \times$. 


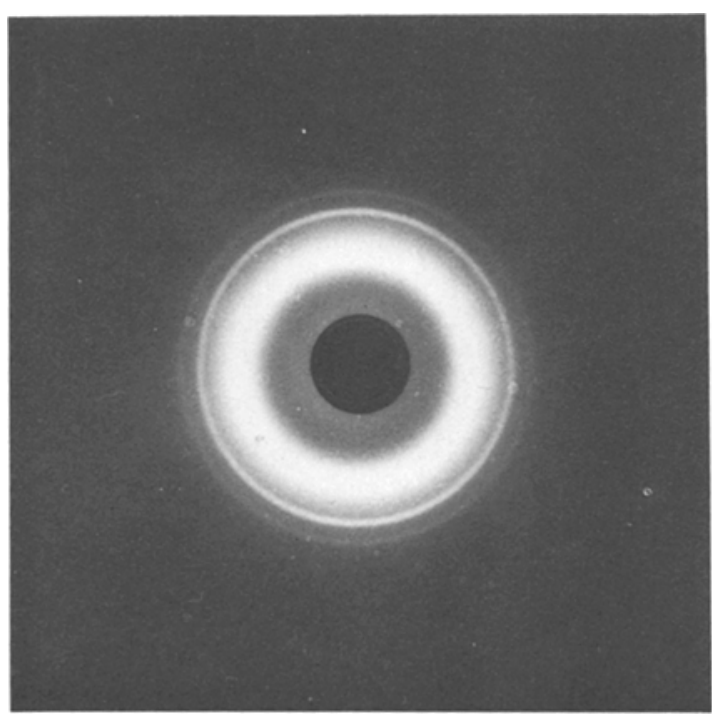

Figure 4 WAXS-pattern of polyethylene/decalin gel.

some weak, but rather sharp reflections. The latter were identified as the (1 10$)$ and (200) reflections of the orthorhombic crystal structure of polyethylene at an angle of $21.5^{\circ}$ and $24.2^{\circ}$, respectively. The diffuse halo at a lower angle is due to the solvent.

Based on the morphological, DSC and WAXS data we arrived at the conclusion that upon quenching the liquid filament a gel fibre was formed, the structure of which is thought to be a macroscopic network of polymer molecules with crystallites acting as physical cross-links. These crystals may very well have a fibrillar nature, since they were generated from a flowing solution of high molecular weight polyethylene [10].

\subsection{Hot drawing}

In the second stage of the solution spinning/ drawing process the polyethylene gel fibre was subjected to hot drawing. It was found that high draw ratios readily could be achieved at temperatures in the range from 90 to $135^{\circ} \mathrm{C}$, i.e. roughly between the "dissolution temperature" of the gel and the melting point of the pure polymer. At lower temperatures frequently fracture occurred upon drawing. A drawing temperature of $120^{\circ} \mathrm{C}$ appeared to be convenient and was maintained throughout the study. On the influence of the drawing temperature will be reported in a forthcoming paper. The strain rate employed was about $1 \mathrm{sec}^{-1}$. After this hot drawing no detectable amount of solvent was left in the highly drawn polyethylene filaments.

\subsection{Mechanical properties}

In Fig. 5 typical stress-strain curves are presented of solution-spun/drawn polyethylene filaments. The draw ratios indicated refer to the reduction in the cross-sectional area of the drawn fibres in comparison with dried undrawn filaments. This area was calculated from the mass per unit length of the fibres, and the density.

Fig. 5 shows that the drawing process drastically improved the mechanical properties of the filaments, which, in fact, is well known for polymeric materials. The Young's modulus, tensile strength and strain at break that were calculated from these stress-strain curves are listed in Table I.

The Young's modulus is plotted against the draw ratio in Fig. 6. As is illustrated in this figure we found a linear relationship between modulus and draw ratio. Similar unique, even if not necessarily linear relations between modulus and draw ratio were previously observed by other authors in drawing $[24,25]$, solid-state extrusion [23] and radial compression of polyethylene rods [9].

The tensile strength of the solution-spun/drawn polyethylene filaments is plotted as a function of the draw ratio in Fig. 7. Also here a simple relation was found, similar to trends previously reported [23]. Like the modulus, the tensile strength initially

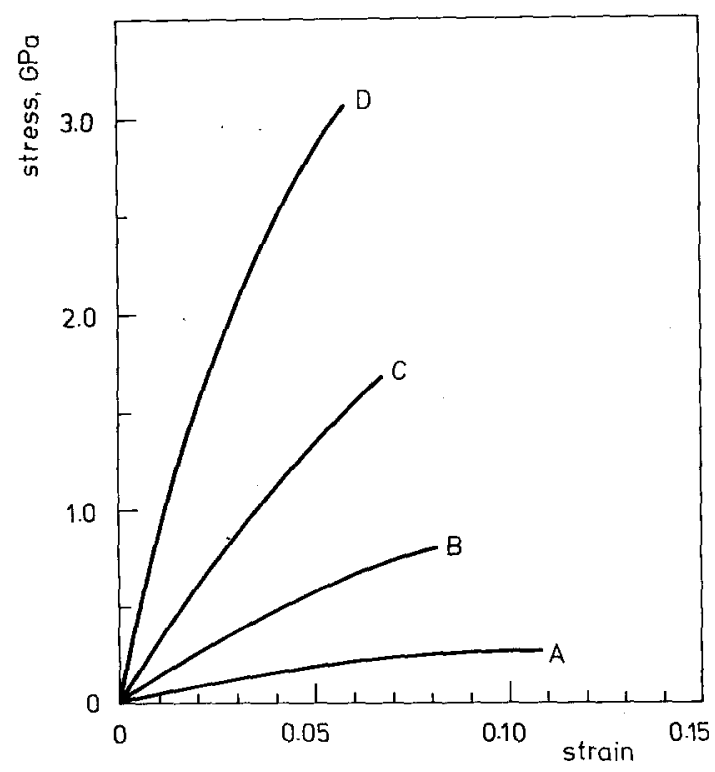

Figure 5 Stress-strain curves of solution-spur/drawn polyethylene fibres. Draw ratios: A 2.8 ; B 8.4; C 15.7; D 31.7 . 
T A BLE I Mechanical properties of solution-spun/drawn polyethylene filaments

\begin{tabular}{rlll}
\hline $\begin{array}{l}\text { Draw } \\
\text { ratio }\end{array}$ & $\begin{array}{l}\text { Modulus } \\
(\mathrm{GPa})\end{array}$ & $\begin{array}{l}\text { Tensile strength } \\
(\mathrm{GPa})\end{array}$ & $\begin{array}{l}\text { Strain } \\
\text { at break }\end{array}$ \\
\hline 1.0 & 2.4 & 0.06 & 0.722 \\
2.8 & 5.4 & 0.27 & 0.108 \\
7.3 & 17.0 & 0.73 & 0.076 \\
8.4 & 17.6 & 0.81 & 0.083 \\
8.6 & 25.1 & 1.17 & 0.090 \\
9.4 & 24.1 & 1.38 & 0.072 \\
9.8 & 27.5 & 1.39 & 0.070 \\
10.3 & 28.3 & 1.52 & 0.074 \\
10.4 & 28.1 & 1.27 & 0.065 \\
11.3 & 23.9 & 1.32 & 0.071 \\
12.1 & 37.5 & 1.65 & 0.074 \\
13.1 & 40.9 & 1.72 & 0.063 \\
13.9 & 32.6 & 1.45 & 0.065 \\
15.7 & 41.2 & 1.80 & 0.068 \\
25.5 & 68.3 & 2.87 & 0.059 \\
31.7 & 90.2 & 3.04 & 0.060 \\
\hline
\end{tabular}

increases linearly with the draw ratio. At high draw ratios, however, the strength tends to approach an upper limit.

It is of interest to note that in the present spinning/drawing technique both the modulus and the tensile strength increase more rapidly with increasing draw ratio than in drawing melt-spun material, or in materials prepared by extrusion and radial compression $[9,23,24]$. It is even more striking that the tensile strength increases as much with increasing draw ratio as the Young's modulus, which can be judged from Table I. This observation is unlike results obtained in the solid-state deformation processes quoted before, where the tensile strength increases much more slowly with the draw ratio than the modulus. Consequently, the tensile strength's of the solution-spun/drawn polyethylene filaments exceed by far the reported values of other drawn and extruded samples. In fact, the tensile strength of $3.0 \mathrm{GPa}$ of a 31.7 times drawn fibre ranks among the highest data of polyethylene fibres obtained by the surface growth technique of Zwijnenburg and Pennings [22].

The strain at break of the filaments rapidly drops with increasing draw ratio to reach a constant value of 0.06 for ratios exceeding 15 , as is illustrated in Fig. 8.

\subsection{Melting behaviour}

This section deals in brief with the thermal properties of the polyethylene fibres, which were studied by differential scanning calorimetry. It should be mentioned that a standard heating rate of $10^{\circ} \mathrm{C}$ $\min ^{-1}$ was adopted in all experiments. It is well known that the highly oriented polymer structures we are currently dealing with may exhibit pronounced superheating effects [28]. Hence the melting temperatures presented in this paper should be compared with those measured under similar conditions.

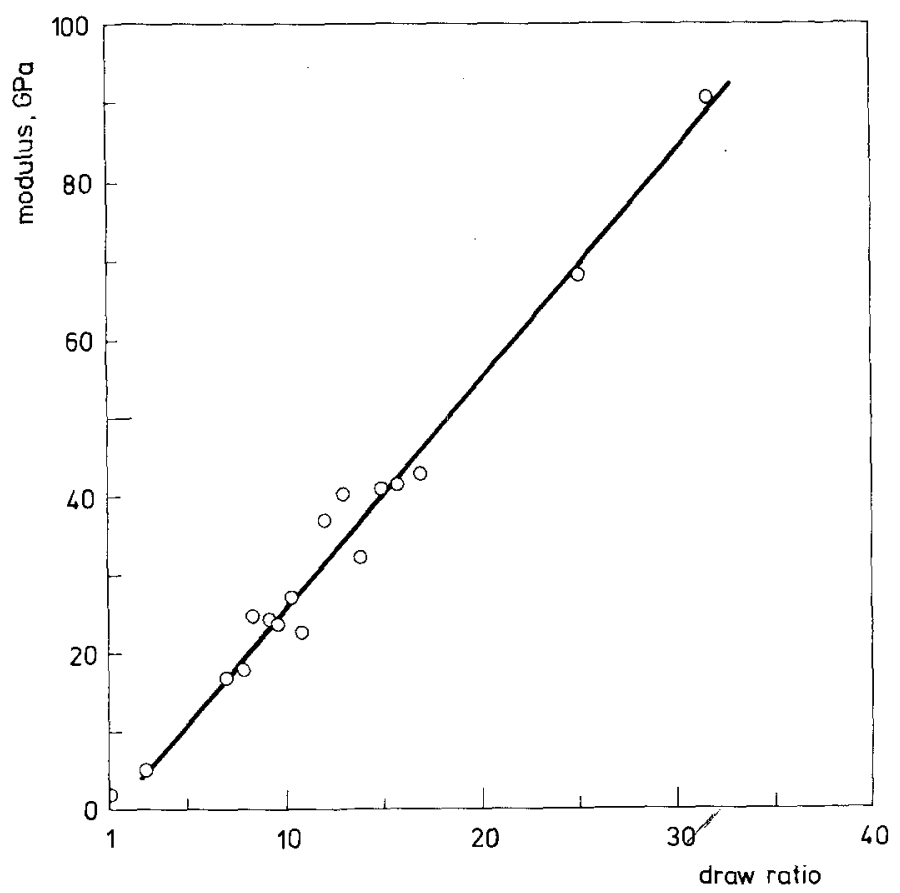

Figure 6 Young's modulus-drawn ratio relationship of polyethylene filaments. 


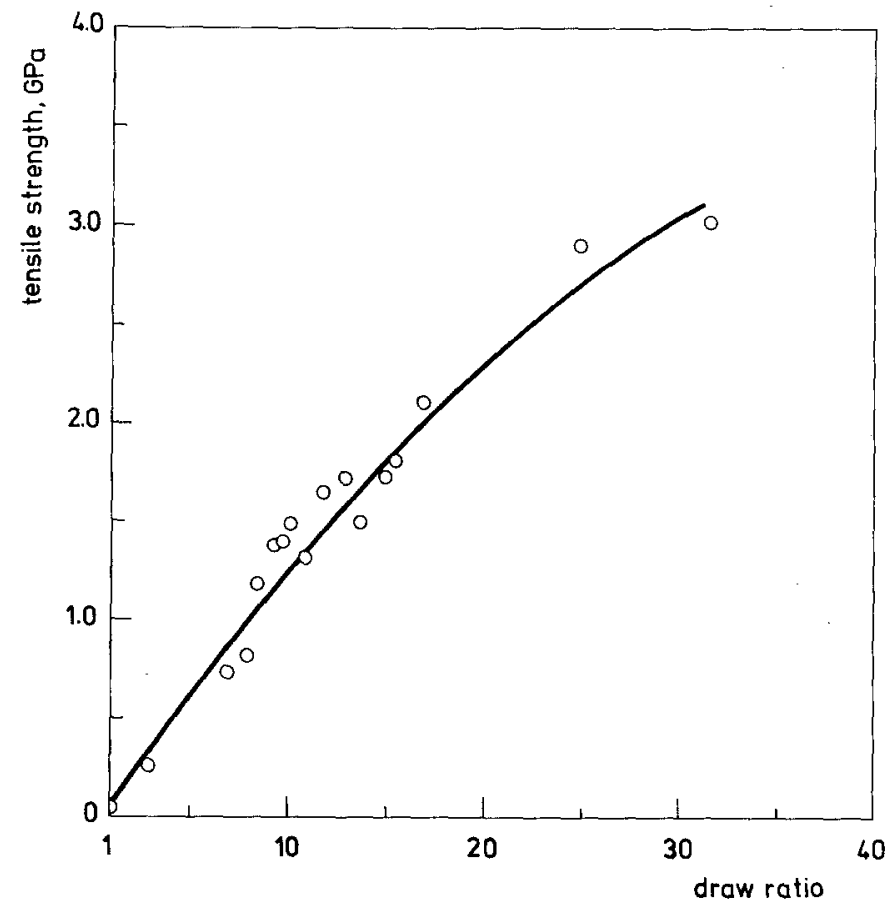

Figure 7 Tensile strength versus draw ratio of polyethylene filaments.

In Fig. 9 DSC-thermograms are presented of the dried undrawn fibre and of fibres with draw ratios of 15.7 and 31.7. Similar to the mechanical properties, the thermal characteristics were found to depend strongly on the draw ratio, as was observed previously by other authors (e.g. [29]). The undrawn monofilament had a peak melting temperature of $133.0^{\circ} \mathrm{C}$ and the 15.7 times drawn fibre $141.0^{\circ} \mathrm{C}$. Curve $\mathrm{C}$ of the filament with a draw ratio of 31.7 exhibits one pronounced maximum at $145.5^{\circ} \mathrm{C}$ and a second small peak at $152.0^{\circ} \mathrm{C}$. This second endotherm may be due to a solid-solid transformation from the orthorhombic crystalline phase to the hexagonal one, as was found in melting longitudinal polyethylene crystals by Pennings and Zwijnenburg [30].

The peak melting temperatures of various polyethylene fibres are presented in Fig. 10. The melting point rapidly increases with draw ratio reaching asymptotically a value of $145.5^{\circ} \mathrm{C}$ at a draw ratio of 31.7 . This value is substantially higher than the melting temperatures of drawn or extruded polyethylene samples $[29,31]$. It agrees very well with the highest melting point of surface

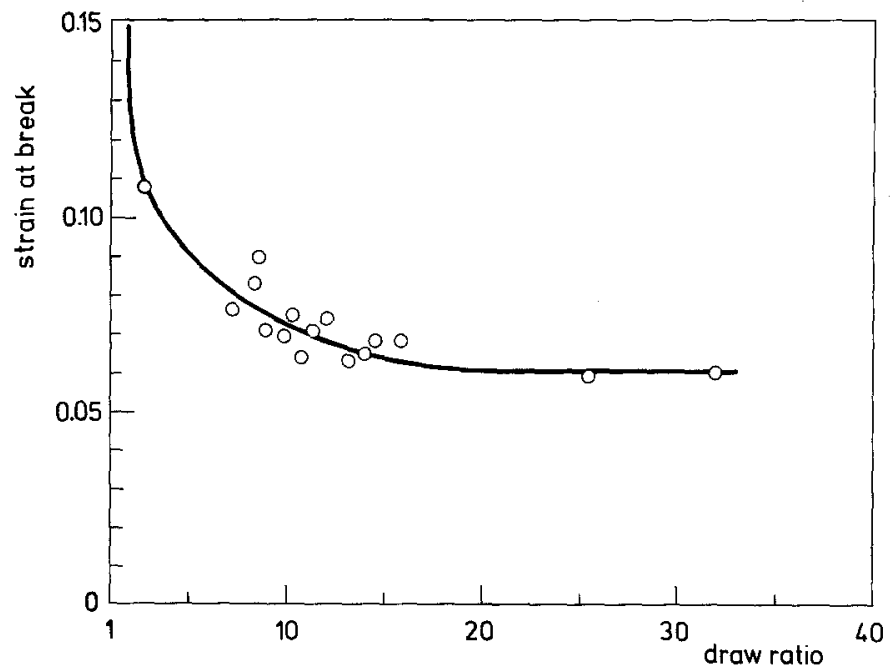

Figure 8 Dependence of the strain at break on the draw ratio. 


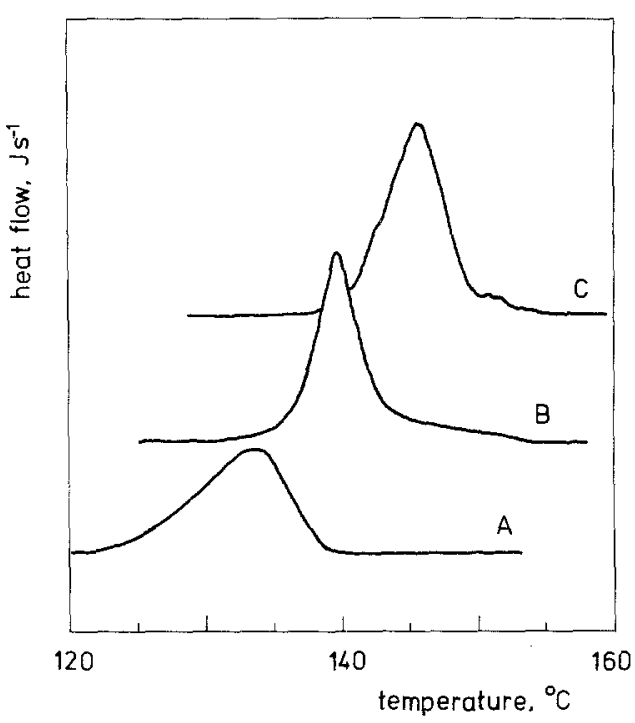

Figure 9 DSC-heating thermograms of solution-spun/ drawn polyethylene fibres. Scan speed $10^{\circ} \mathrm{C} \mathrm{min}^{-1}$. Draw ratios: A 1; B 15.7; C 31.7.

grown longitudinal crystals, measured under identical conditions [30].

The heat of fusion of the filaments showed a similar dependence on the draw ratio as the melting temperature. The value of the dried undrawn sample was $163 \mathrm{~J} \mathrm{~g}^{-1}$. The heat of fusion of the drawn fibres rapidly increased with the draw ratio, reaching a value of $260 \mathrm{~J} \mathrm{~g}^{-1}$ at a ratio of 31.7 . This corresponds to an increase in crystallinity from 56 to $90 \%$ if based on a value of $293 \mathrm{~J} \mathrm{~g}^{-1}$ for fully crystalline polyethylene.

\subsection{Structure}

Some morphological and structural features of the solution-spun/drawn polyethylene filaments revealed by optical and scanning electron microscopy

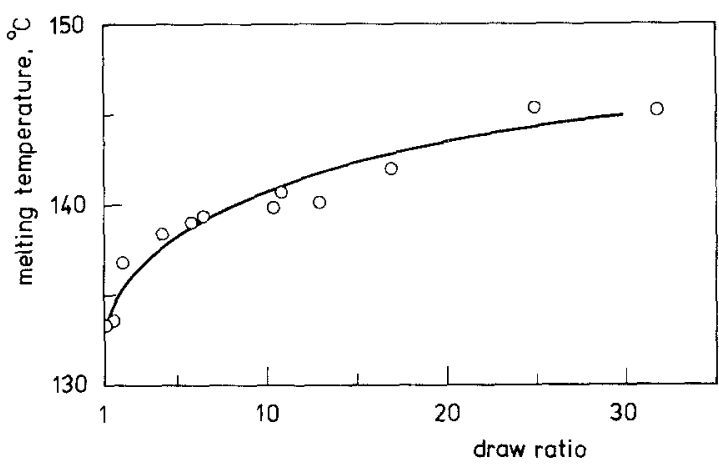

Figure 10 DSC-(peak)melting temperatures versus draw ratio of polyethylene monofilaments. and X-ray scattering will be described in this section.

Fig. 11 displays optical micrographs of dried undrawn (a) and 25.5 times drawn $(b, c)$ fibres as viewed between crossed polarizers. The undrawn filament consisted of crystalline entities with no preferential orientation. The drawn fibre appeared, by contrast, to be uniformly oriented and highly bi-refringent (Fig. 11b). At higher magnifications (Fig. 11c) well-oriented striations were discerned in the filaments. The cross-sectional shape of the fibres was frequently found to be rectangular. For instance, the specimen shown in Figs. $11 \mathrm{~b}$ and $\mathrm{c}$ had a thickness and a width of $8 \mu \mathrm{m}$ and $80 \mu \mathrm{m}$, respectively. The cause for this rectangular shape may be found in the fact that the wet gel fibre was wound up on a bobbin prior to drawing, which might have resulted in some lateral deformation.

The striations in the highly drawn filaments were seen in greater detail in the scanning electron microscope. The SEM photograph in Fig. 12 shows a polyethylene filament with a draw ratio of 31.7. The diameter of this fibre is $20 \mu \mathrm{m}$. This micrograph reveals that the surface of the filament is rather uniform and smooth, and has a fibrillar nature.

Information about the molecular arrangement in the drawn polyethylene filaments was obtained by wide-angle X-ray scattering. Fig. 13 shows WAXS-patterns of fibres with draw ratios of 1.5 (a), 15.7 (b) and 31.7 (c). The diffraction patterns are characterized by the typical $(110)$ and $(200)$ reflections of the orthorhombic polyethylene unit cell. The 1.5 times drawn fibre shows a slight $c$ and $a$-axis orientation. The latter type of orientation was reported previously for polyethylene specimens with low draw ratios [32]. From Figs. $13 \mathrm{~b}$ and $\mathrm{c}$ it was inferred that increasing draw ratio leads, expectedly, to a drastic increase in orientation of the polymer molecules in the fibre direction.

The highly drawn fibres did not display a discrete reflection in the small-angle region of the X-ray scattering pattern, which points to a rather continuous crystalline nature of these filaments.

\section{Discussion}

In this paper we presented a simple route to produce high-strength and high-modulus polyethylene filaments. There seems to be a close resemblance between the solution-spinning/drawing process and 

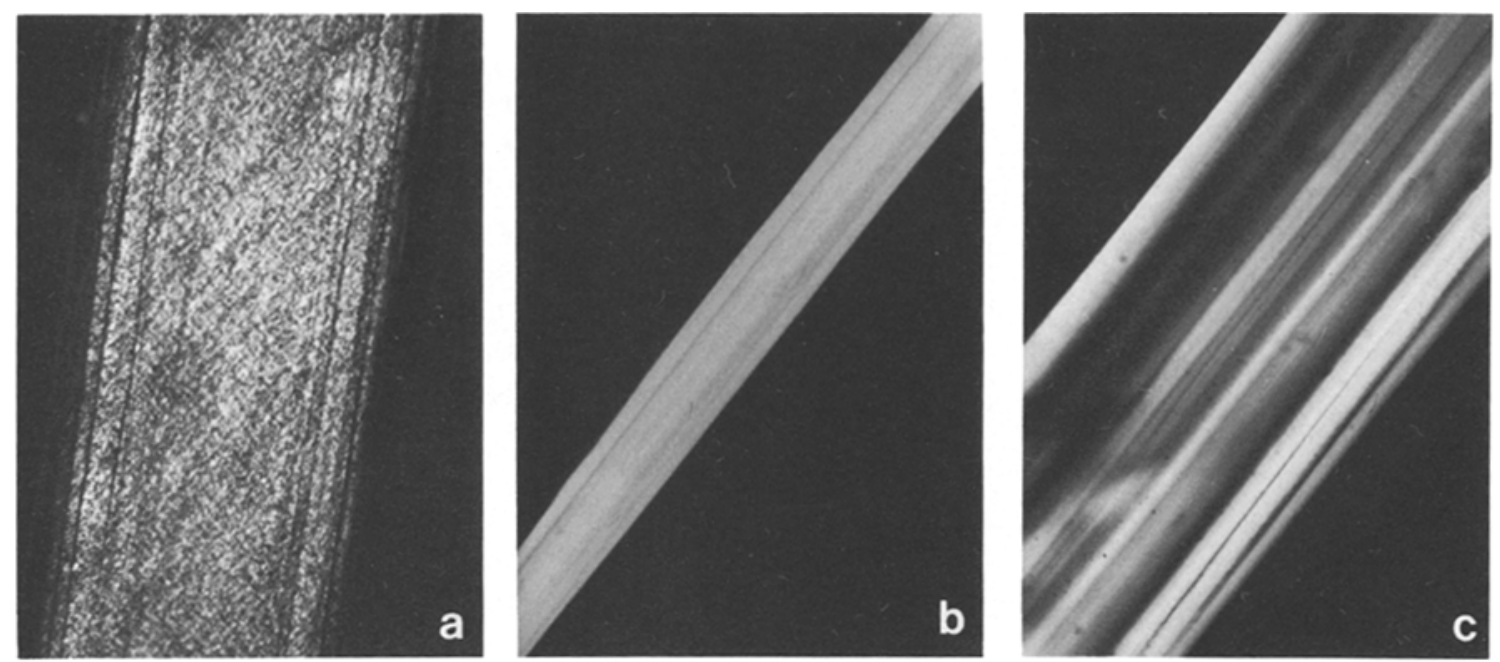

Figure 11 Optical micrographs of polyethylene fibres. Crossed Nicols. a draw ratio 1 , magnification $96 \times$; b draw ratio 25.5, magnification $120 \mathrm{x}$; $\mathrm{c}$ draw ratio 25.5 , magnification $480 \mathrm{x}$.

the well-known drawing and extrusion techniques. This is indicated by the draw ratio/modulus, strength or melting temperature relationships observed in the three methods. It should be noted, however, that the effectiveness of the present drawing process, the tensile strength and, to a lesser extent, the modulus and melting point of the fibres produced are superior in comparison with the other two techniques. The cause for this difference is found both in the molecular weight of the polymer used, and in a drastically increased effective drawability of high molecular weight polyethylene that is spun or cast from dilute solutions, related to melt-processed material [33]. These topics will be dealt with extensively in future papers.

The properties of the solution-spun/drawn fibres and the crystals obtained by the surface growth

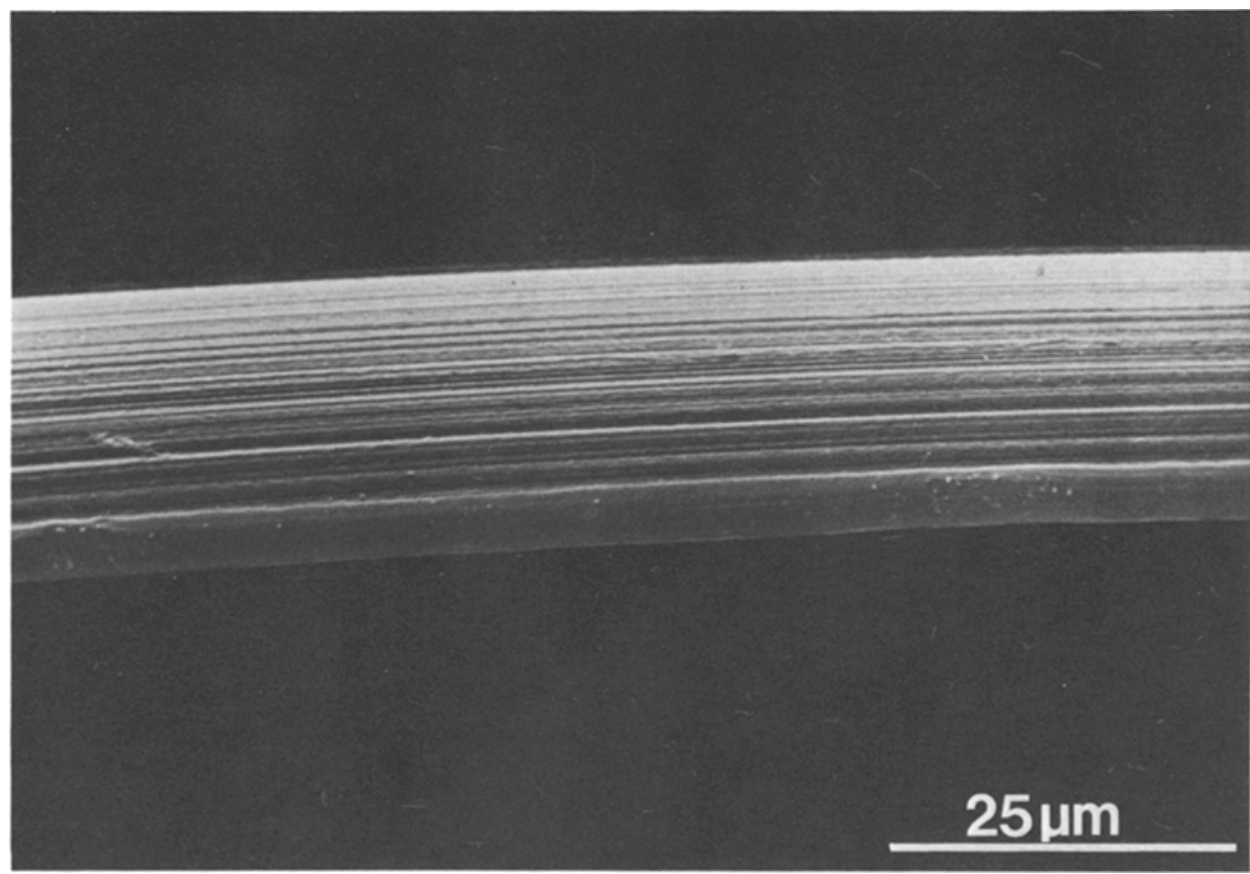

Figure 12 Scanning electron micrograph of a 31.7 times drawn polyethylene fibre. 

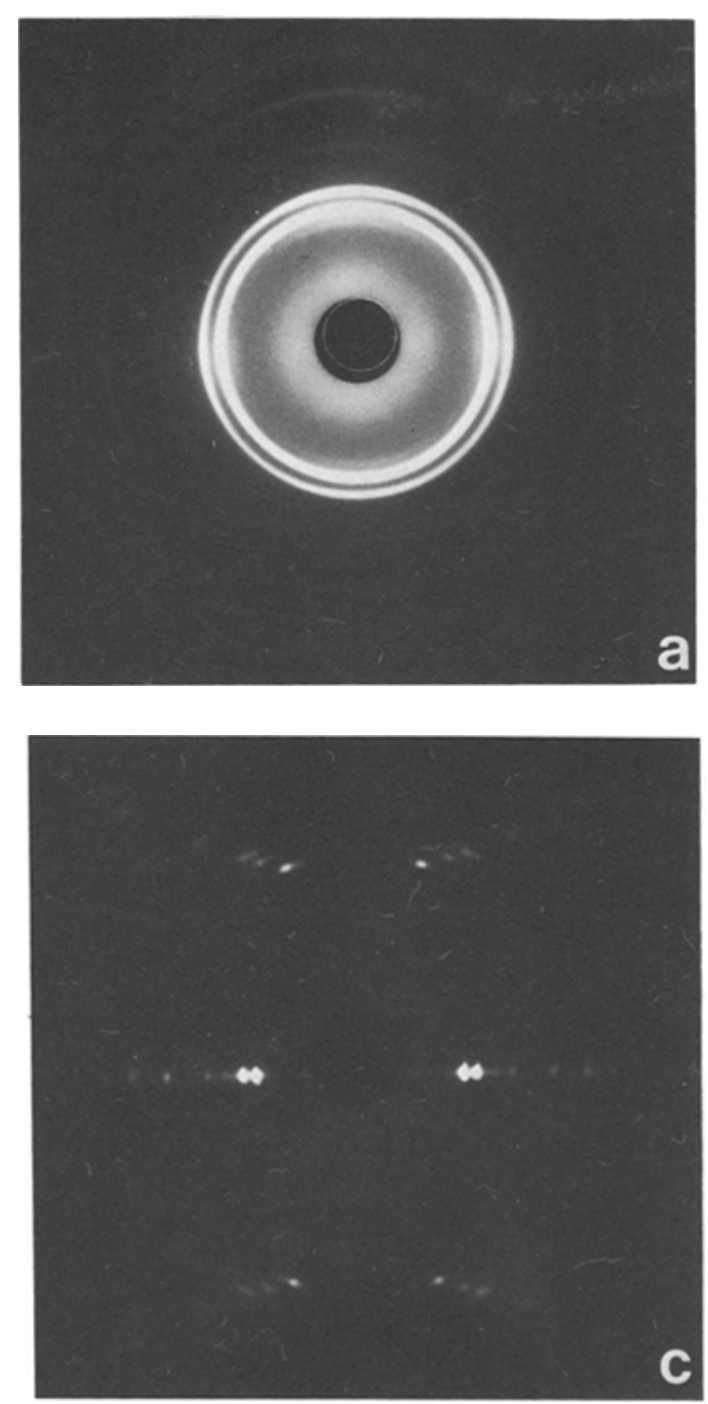

method show striking similarities, which prompts a comparison of these two seemingly different processes. At this stage, however, this appears to be rather premature in view of the scarcity of the available information. Nevertheless, recent observations by Barham et al. [34] concerning gel formation in dilute solutions of high molecular weight polyethylene and its relation to the socalled surface growth technique point to a basically identical mechanism of fibre formation. This mechanism involves the generation of a physical network of the polymer. In the surface growth process this gel is formed around the rotor of the Couette-apparatus, and in the present method the macromolecular network is formed in the solution-spinning/quenching stage. Subsequently the polymer gel is subjected to very large defor-

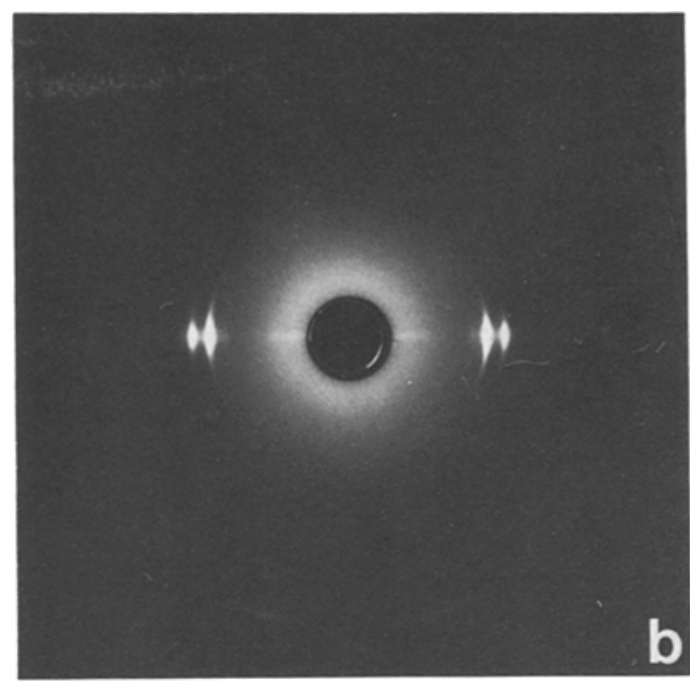

Figure 13 WAXS-patterns of drawn polyethylene filaments. Draw ratios: a $1.5 ;$ b 15.7 ; c 31.7 . Fibre axis vertical.

mations by pulling alongside the rotor surface, or simply by hot drawing, to yield a highly oriented structure.

\section{Acknowledgement}

The authors thank J. M. P. Smeets and the Department of Physical Chemistry of DSM for assistance in the experimental work.

\section{References}

1. A. PETERLIN and G. MEINEL, J. Polymer Sci B 3 (1965) 783.

2. K. YAMADA, M. KAMAZAWA and M. TAKAYANAGI, Polymer Preprints Amer. Chem. Soc. (1979) 780 .

3. M. TAKAYANAGI, K. IMADA and T. KAJIYAMA, J. Polymer Sci. C 15 (1966) 263.

4. J. H. SOUTHERN and R. S. PORTER, J. Appl. Polymer Sci. 14 (1970) 2305.

5. P. PREDECKI and W. O. STATTON, J. Polymer Sci. B 10 (1972) 87.

6. A. G. GIBSON, I. M. WARD, B. N. COLE and B. PARSONS, J. Mater. Sci. 9 (1974) 1193.

7. G. CAPACCIO and I. M. WARD, Polymer 15 (1974) 233.

8. E. S. CLARK and L. S. SCOTT, Polymer Eng. Sci. 14 (1974) 682.

9. P. D. GRISWOLD, R. S. PORTER, C. R. DESPER and R. J. FARRIS, ibid. 18 (1978) 537.

10. A. J. PENNINGS, J. M. A. A. VAN DER MARK and H. C. BOOIJ, Kolloid Z.- Z. Polymere 236 (1970) 99.

11. A. ZWIJNENBURG and A. J. PENNINGS, Colloid \& Polymer Sci. 253 (1975) 452.

12. F. C. FRANK, A. KELLER and M. R. MACKLEY, 
Polymer 12 (1971) 467.

13. M. R. MACKLEY and A. KELLER, Phil. Trans. Roy. Soc. (London) A278 (1975) 29.

14. A. J. McHUGH and J. M. SCHULTZ, Kolloid Z.- $Z$. Polymere 251 (1973) 193.

15. A. KELlER, J. Polymer Sci. 15 (1955) 31.

16. H. D. KEITH, F. J. PADDEN and R. G. VADIMSKY, J. Appl. Phys. 37 (1966) 4027.

17. A. PETERLIN, Polymer Eng. Sci. 14 (1974) 627.

18. A. ZWIJNENBURG and A. J. PENNINGS, Colloid \& Polymer Sci. 254 (1976) 868.

19. A. J. PENNINGS, J. Polymer Sci. Polymer Symp. 59 (1977) 55.

20. A. J. MchUGH, J. Appl. Polymer Sci. 19 (1975) 125.

21. A. J. PENNINGS, C. J. H. SCHOUTETEN and A. M. KIEL, J. Polyer Sci. C. 38 (1972) 167.

22. A. ZWIJNENBURG and A. J. PENNINGS, J. Polymer Sci. Polymer Lett. 14 (1976) 339.

23. S. KOJIMA and R. S. PORTER, J. Polymer Sci. Polymer Phys. Ed. 16 (1978) 1729.

24. G. CAPACCIO and I. M. WARD, Polymer 16 (1975) 239.
25. P. J. BARHAM and A. KELlER, J. Mater. Sci. 11 (1976) 27.

26. P. SMITH, P. J. LEMSTRA, B. KALB and A. J. PENNINGS, Polymer Bull. 1 (1979) 733.

27. B. WUNDERLICH, "Macromolecular Physics", Vol. 2 (Academic Press, New York, 1976). p. 390.

28. B. WUNDERLICH and G. CZORNYJ, Macromolecules 10 (1977) 906.

29. J. CLEMENTS, G. CAPACCIO and I. M. WARD, J. Polymer Sci. Polymer Phys. Ed. 17 (1979) 693.

30. A. J. PENNINGS and A. ZWIJNENBURG, J. Polymer Sci. Polymer Phys. Ed. 17 (1979) 1011.

31. S. KOJIMA, C. R. DESPER and R. S. PORTER, ibid. 16 (1978) 1721.

32. J. T. JUDGE and R. S. STEIN, J. Appl. Phys. 32 (1961) 2357.

33. P. SMITH and P. J. LEMSTRA, Die Makromol. Chem. (in press).

34. P. J. BARHAM, M. J. HILL, C. G. CANNON and A. KELLER, Polymer Lett. (submitted).

Received 27 September and accepted 12 October 1979. 